\title{
PENGUJIAN AKTIVITAS ANTIMIKROBA EKSTRAK KULIT DAN KAYU RANTING SENGON (FALCATARIA MOLUCCANA) DENGAN PELARUT N- HEKSANA, ETIL ASETAT DAN METANOL TERHADAP Enterobacteriaceae, Staphylococcus aureus DAN Candida albicans
}

\section{Antimicrobial activities test of bark and wood branch Sengon (Falcataria moluccana) extract with n-Hexane, ethyl acetate and methanol solvent on Enterobacteriaceae, Staphylococcus aureus and Candida albicans}

\author{
Dheanna P.S Rachmawati ${ }^{1}$, Khairin Rabbani ${ }^{1}$, Alfi Rumidatul ${ }^{2}$ \\ Feldha Fadhila ${ }^{1}$, Yayan Maryana ${ }^{3}$ \\ ${ }^{1}$ Jurusan Teknilogi Laboratorium Medik Institut Kesehatan Rajawali \\ ${ }^{2}$ Sekolah Ilmu dan Teknologi Hayati ITB \\ ${ }^{3}$ Prodi Farmasi Politeknik Meta Industri
}

Koresponden: alfi@ sith.itb.ac.id/+62 222511575

\begin{abstract}
Infection disease still become a disease that happen most of the time, so antibiotic treatment sometimes used inappropriately and inflict resistence towards some pathogen microorganism. Several research of secondary metabolite compounds have been carried out, such as bark and wood branch of Sengon. This study aims to determine the antmicrobial activity of bark and wood branch of Sengon extract against Enterobacteriaceae, Staphylococcus aureus and Candida albicans. The method of antimicrobial activity test used was diffusion with Kirby-bauer technique. The result showed that the highest inhibition zone formed in 11\%. With the measurement of the highest average total inhibition zone resulted from the part of the sick wood with ethyl acetate solvent against Salmonella typhi with an average total inhibition zone of $5.5 \mathrm{~mm}$, healthy skin with n-hexane solvent produced the smallest inhibition zone with a total mean of $1.94 \mathrm{~mm}$. As for bacteria that cannot be inhibited growth are Escherichia coli and Klebsiella pneumonia.
\end{abstract}

Keywords : Falcataria moluccana, Enterobacteriaceae. Staphylococcus aureus, Candida albicans

\begin{abstract}
ABSTRAK
Penyakit infeksi masih menjadi penyakit yang banyak diderita sehingga pengobatan antibiotik terkadang digunakan secara tidak tepat dan menimbulkan resistensi terhadap beberapa mikroorganisme patogen. Beberapa penelitian terhadap bahan alam mulai dilakukan, salah satunya terhadap kulit dan kayu ranting Sengon. Tujuan penelitian ini adalah untuk menguji aktivitas antibakteri ekstrak kulit dan kayu Sengon terhadap bakteri family Enterobacteriaceae, Staphylococcus aureus dan Candida albicans. Metode uji aktivitas antibakteri difusi agar dilakukan dengan teknik Kirby-bauer. Pada penelitian ini, zona hambat terbesar pada masing-masing mikroorganisme berada pada konsentrasi $11 \%$. Dengan pengukuran rerata total zona hambat tertinggi dihasilkan dari bagian kayu sakit dengan pelarut etil asetat terhadap Salmonella typhi dengan rerata total zona hambat 5,5 $\mathrm{mm}$, kulit sehat dengan pelarut $\mathrm{n}$-heksana menghasilkan zona hambat paling kecil dengan rerata total 1,94 $\mathrm{mm}$. Adapun bakteri yang tidak dapat dihambat pertumbuhannya adalah
\end{abstract}


Escherichia coli dan Klebsiella pneumonia.

Kata kunci : Falcataria moluccana,

Enterobacteriaceae, Candida albicans, Staphylococcus aureus

\section{PENDAHULUAN}

Penyakit infeksi masih menjadi penyakit yang banyak diderita oleh masyarakat di negara berkembang seperti Indonesia, contohnya penyakit infeksi saluran pernapasan, infeksi saluran pencernaan, infeksi saluran kemih dan infeksi jamur. Salah satu terapi pengobatan yang dapat diberikan tenaga medis untuk mengobati penyakit infeksi salah satunya adalah antibiotik. Penggunaan antibiotik yang tidak tepat menyebabkan terjadinya perkembangan bakteri yang resisten terhadap antibiotik (Desrini, 2015). Resistensi bakteri terhadap beberapa antibiotik ini menjadi masalah yang cukup besar di dunia.

Beberapa penelitian terhadap bahan alam mulai dilakukan dengan tujuan dapat menghambat bakteri yang resisten terhadap antibiotik. Tumbuhan obat telah banyak digunakan oleh berbagai lapisan masyarakat dunia, baik di negara berkembang maupun negara maju. Sekitar $80 \%$ penduduk negara berkembang masih mengandalkan pengobatan tradisional yang dalam prakteknya menggunakan tumbuhtumbuhan (Benigna, 2015). Salah satu tumbuhan yang mulai diteliti kandungan bahan alamnya adalah tanaman Sengon (Falcataria moluccana)

Sengon adalah salah satu jenis tanaman penghasil kayu yang banyak tumbuh di Indonesia. Menurut penelitian Eleanore (2013), ekstrak tanaman Sengon ternyata memiliki kandungan senyawa metabolit sekunder yang memiliki aktivitas antibakteri, senyawa tersebut adalah alkaloid, saponin, tanin dan flavonoid. Selain itu, kulit dan kayu pohon Sengon yang terinfeksi penyakit juga dapat memproduksi senyawa fenolik, flavonoid, steroid, terpenoid, alkaloid, saponin dan antioksidan (Fahrizal, 2014; Rosdiana, 2017). Pada penelitian Ramidatul et al. (2018), ditemukan bahwa pada kulit sakit ranting sengon mengandung senyawa fenolik, flavonoid, saponin dan tanin.

Pelarut yang digunakan pada penelitian ini adalah n-heksana, etil asetat dan metanol yang pada beberapa penelitian terbukti tidak memiliki kemampuan menghambat pertumbuhan bakteri. Pada penelitian milik Miradiana et al. (2017), pelarut n-heksana digunakan sebagai kontrol negatif yang pada hasilnya menyatakan bahwa pelarut tersebut tidak dapat menghambat pertumbuhan bakteri yang diujikan. Sejalan dengan penelitian Miradiana, pada penelitian Amalia et al. (2017) dan Opa et al. (2018) menyatakan bahwa pelarut etil asetat dan metanol tidak menghambat pertumbuhan bakteri yang diujikan pada masing-masing penelitian.

Pada penelitian ini, dilakukan pengujian aktivitas antimikroba ekstrak kulit sehat, kulit sakit dan kayu sakit pohon Sengon (Falcataria moluccana) dengan pelarut $\mathrm{n}$-heksana, etil asetat dan metanol terhadap Salmonella typhi, Shigella dysenteriae, Klebsiella pneumoniae, Escherichia coli, Proteus mirabilis, Pseudomonas aeruginosa, Staphylococcus dan Candida albicans.

\section{METODE}

Penelitian ini dilaksanakan di Laboratorium Mikrobiologi Kampus I Institut Kesehatan Rajawali pada bulan Februari 2020. Dengan metode uji aktivitas antibakteri difusi agar dan dilakukan dengan teknik Kirby-bauer.

Penelitian diawali dengan melakukan ekstraksi pada simpliasia dengan teknik maserasi. Selanjutnya 
langkah identifikasi mikroorganisme uji dengan pewarnaan Gram dan dilanjutkan dengan pembuatan kurva tumbuh yang bertujuan untuk mengetahui waktu pengambilan koloni yang optimal, yang mana berada pada fase pertumbuhan (fase logaritmik). Setelah didapatkan waktu optimum masing-masing mikroorganisme uji, pengujian aktivitas antimikroba dilakukan dengan metode difusi agar dengan teknik Kirby-bauer. Koloni yang telah cukup umur distandarisasi terlebih dahulu dengan standar Mac Farland 0,05\%, suspensi tersebut lalu digoreskan pada permukaan medium dengan swab steril. Cakram berisi $20 \mu 1$ ekstrak dengan konsentrasi $9 \%, 9.5 \%, 10 \%, 10.5 \%$ dan $11 \%$ yang telah direndam selama 1 jam ditempelkan pada permukaan medium yang telah kering, sertakan kloramfenikol sebagai kontrol positif dan cakram berisi akuades sebagai kontrol negatif, diinkubasi selama 48 jam untuk bakteri dan 120 jam untuk jamur pada suhu $37^{\circ} \mathrm{C}$, diamati dan diukur zona bening yang terbentuk disekitar kertas cakram. Zona bening yang terbentuk diukur dengan jangka sorong sebanyak 3 kali pengukuran dan dicari rerata dari hasil pengukuran zona bening yang terbentuk pada ulangan 1 dan ulangan 2 dari masing-masing bakteri.

\section{HASIL}

Berdasarkan hasil pengamatan mikroskopis dengan pewarnaan Gram, Salmonella typhi, Shigella dysenteriae, Klebsiella pneumoniae, Escherichia coli, Proteus mirabilis dan Pseudomonas aeruginosa tampak berwarna merah yang berarti termasuk ke dalam golongan Gram negatif. Sedangkan Staphylococcus aureus dan Candida albicans tampak berwarna ungu yang berarti termasuk ke dalam golongan Gram positif.
Berdasarkan Tabel 01. Hasil identifikasi morfologi sel dibawah mikroskop dengan perbesaran 40x Candida albicans tampak berwarna ungu dengan bentuk blastoconodia. Salmonella typhi tampak berwarna merah, berbentuk basil tunggal yang memanjang. Klebsiella pneumoniae dan Pseudomonas aeruginosa tampak berwarna merah, berbentuk basil pendek berpasangan. Shigella dysenteriae dan Escherchia coli tampak berwarna merah, berbentuk basil pendek tunggal. Proteus mirabilis berbentuk batang pendek, berkelompok dan berwarna merah. Sedangkan pada Staphylococcus aureus berbentuk bulat, bergerombol (seperti buah anggur), dan berwarna ungu.

Penelitian dilanjutkan dengan pembuatan kurva pertumbuhan, dengan tujuan untuk untuk menentukan waktu pengambilan koloni yang optimal, yang mana berada pada fase pertumbuhan (fase logaritmik) dari mikroorganisme uji. Pada fase ini, kecepatan pertumbuhan mikroorganisme uji dipengaruhi oleh medium tempatnya tumbuh dan kondisi lingkungannya yang mana cocok untuk dilakukan pengujian aktivitas antimikroba (Hamdiyati, 2011).

Berdasarkan Tabel 02. Hasil kurva pertumbuhan fase $\log$ Candida albicans mulai terlihat pada jam ke-12 sampai jam ke-54, Salmonella typhi, Shigella dysenteriae, Escherchia coli dan Pseudomonas aeruginosa pada jam ke-6 sampai jam ke-24, Klebsiella pneumoniae pada jam ke-6 sampai jam ke-27, Proteus mirabilis pada jam ke-15 sampai jam ke-24 dan Staphylococcus aureus pada jam ke-3 sampai jam ke-21. Sedangkan waktu pengambilan optimum untuk pengujian aktivitas antimikroba pada masing-masing mikroorganisme uji sebagai berikut, Candida albicans pada jam ke-30, Salmonella typhi dan Klebsiella pneumoniae pada jam ke-18, Shigella dysenteriae dan Escherchia coli 
pada jam ke-15, Proteus mirabilis pada jam ke-21, Pseudomonas aeruginosa pada jam ke-12 dan Staphylococcus aureus pada jam ke-6.

Uji aktivitas antimikroba dilakukan setelah mengetahui waktu pengambilan optimum. Hasil pengujian berupa zona hambat yang terbentuk di sekitar cakram yang selanjutnya diukur menggunakan jangka sorong manual dengan ketelitian milimeter ( $\mathrm{mm}$ ) sebanyak tiga kali pengukuran yang lalu dibuat rerata.

Berdasarkan tabel 03. Hasil penelitian menunjukkan zona hambat terbesar yang terbentuk pada ekstrak kulit dan kayu ranting Sengon dengan pelarut n-heksana, etil asetat dan metanol terhadap Salmonella typhi, Shigella dysenteriae, Klebsiella pneumoniae, Escherchia coli, Proteus mirabilis, Pseudomonas aeruginosa, Staphylococcus aureus dan Candida albicans berada pada konsentrasi $11 \%$. Pada ekstrak kulit dan kayu sakit ranting sengon dengan pelarut etil asetat serta kulit sehat ranting sengon dengan pelarut n-heksana terhadap Salmonella typhi, zona hambat terbesar terbentuk pada ekstrak kayu sakit diikuti kulit sakit dan sehat ranting sengon dengan diameter rerata $9,1 \mathrm{~mm}, 4,7 \mathrm{~mm}$ dan $2,9 \mathrm{~mm}$. Adapun zona hambat terbesar yang terbentuk pada ekstrak kulit sehat ranting sengon dengan pelarut n-heksana yaitu terhadap Shigella dysenteriae diikuti Candida albicans dengan diameter rerata 7,3 $\mathrm{mm}$ dan $6,9 \mathrm{~mm}$. Sedangkan pada hasil pengukuran zona hambat ekstrak kulit sehat ranting Sengon dengan pelarut etanol, zona hambat terbesar terbentuk terhadap Proteus mirabilis diikuti Pseudomonas aeruginosa dan Staphylococcus aureus dengan diameter rerata sebesar $4,7 \mathrm{~mm}$, 4,3 $\mathrm{mm}$ dan $3,3 \mathrm{~mm}$.

\section{PEMBAHASAN}

Gram, $\begin{array}{r}\text { Berdasarkan hasil pewarnaan } \\ \text { terdapat enam }\end{array}$ mikroorganisme uji termasuk ke dalam golongan Gram negatif dan dua mikroorganisme uji lainnya termasuk ke dalam golongan Gram positif. Hasil pewarnaan Gram positif akan berwarna ungu, sedangkan Gram negatif akan berwarna merah. Pada sel Gram negatif, kristal violet akan larut saat pencucian dengan alkohol. Hal ini disebabkan oleh sel Gram negatif memiliki lapisan peptidoglikan yang tipis sehingga tidak mampu mengikat larutan kristal violet dengan kuat (Rahayu, 2017). Maka dari itu, saat Gram negatif diberi pewarna pembanding Safranin yang berwarna merah, dinding sel akan terwarnai dengan sempurna. Lapisan dinding sel Gram negatif yang utuh dapat menghasilkan warna merah yang terlihat jelas, pewarnaan Gram dapat tampak keunguan jika organisme sudah tua, mati atau rusak yang disebabkan oleh agen antimikroba (Ryan et al., 2004). Dalam pewarnaan Gram, Candida albicans akan tampak sel ragi (khamir/yeast) berbentuk blastoconodia dengan golongan Gram positif (Kayser et al., 2005). Berdasarkan hasil pewarnaan Gram yang telah dilakukan, warna yang tampak pada golongan Gram negatif terlihat sedikit keungunan. Diduga, hal ini disebabkan oleh penggunaan mikroorganisme yang sudah tua saat dilakukan pewarnaan.

Pembuatan kurva pertumbuhan merupakan bagian yang penting dari suatu penelitian karena dapat mengetahui prediksi populasi setiap mikroorganisme dalam jangka waktu yang sama (Fauziah, 2013). Kurva pertumbuhan umumnya terjadi dalam 4 fase, antara lain fase lag atau fase adaptasi, fase log atau fase eksponensial, fase stasioner dan fase kematian.

Berdasarkan

pertumbuhan, Salmonella kurva typhi 
mengalami fase log mulai terlihat pada jam ke-6 sampai jam ke-24. Pada penelitian Sahribulan et al. (2018) fase log Salmonella typhi mulai terlihat pada jam ke-4 sampai ke-22, sedangkan pada penelitian milik Pratiwi (2015), fase log Salmonella typhi mulai terlihat pada jam ke-10 sampai jam ke-19. Pada fase log Staphylococcus aureus mulai terlihat pada jam ke-3 hingga jam ke-21, sedangkan hasil kurva pertumbuhan yang dilakukan oleh Ristiati (2015), fase log mulai terlihat pada jam ke-4 hingga jam ke-12. Perbedaan hasil kurva tumbuh pada penelitian tersebut dapat disebabkan oleh lingkungan pertumbuhan mikroorganisme yang berbeda. Beberapa faktor yang dapat mempengaruhi pertumbuhan mikroorganisme diantaranya $\mathrm{pH}$, suhu, oksigen, cahaya dan nutrien.

Berdasarkan hasil uji aktivitas antibakteri terhadap pertumbuhan Salmonella typhi, ekstrak kayu dan kulit sakit ranting Sengon dengan pelarut etil asetat memiliki kemampuan lebih tinggi dibanding kulit sehat ranting sengon dengan pelarut n-heksana. Diduga, hal ini disebabkan oleh tingginya kadar senyawa metabolit sekunder pada ekstrak kayu dan kulit sakit dibanding ekstrak kulit sehat. Penggunaan pelarut etil asetat diduga mempengaruhi kadar senyawa metabolit sekunder pada ekstrak kayu dan kulit sakit. Menurut Ngazizah et al. (2016), ekstrak dengan pelarut etil asetat dapat membentuk zona hambat yang besar sebab etil asetat bersifat semipolar. Senyawa dengan pelarut ini memiliki afinitas lebih tinggi untuk berinteraksi dengan dinding sel.

Berdasarkan hasil zona hambat ekstrak kulit sehat ranting sengon dengan pelarut n-heksana, Candida albicans memiliki zona hambat lebih kecil dibanding Shigella dysenteriae. Diduga, senyawa metabolit sekunder yang terkandung dalam ekstrak kulit sehat ranting Sengon tidak cukup adekuat untuk menghambat pertumbuhan Candida albicans, meskipun ekstrak kulit sehat memiliki kandungan senyawa metabolit sekunder yang bersifat antijamur. Dugaan ini diperkuat oleh penelitian Kurniawan (2015) yang mana pada penelitiannya, ekstrak etanol daun kelor tidak dapat menghambat pertumbuhan Candida albicans meskipun ekstrak tersebut memiliki kandungan senyawa metabolit sekunder yang lebih kompleks.

Dari hasil penelitian ekstrak kulit sehat ranting sengon dengan pelarut metanol, zona hambat terbesar terbentuk pada Proteus mirabilis, sedangkan Staphylococcus aureus memiliki zona hambat terendah. Hal ini mengartikan bahwa Gram negatif lebih rentan terhadap senyawa aktif antibakteri kulit sehat ranting Sengon dibanding bakteri Gram positif. Diduga, hal ini disebabkan oleh perbedaan struktur dinding sel bakteri Gram negatif dan Gram positif. Dugaan ini diperkuat oleh pernyataan Simorangkir et al. (2019), dimana bakteri Gram negatif memiliki gugus protein yang bersifat hidrofilik dan dapat dengan mudah ditembus oleh senyawa polar pada ekstrak etanol.

Hasil uji aktivitas antibakteri terhadap Klebsiella pneumoniae dan Escherchia coli pada ekstrak kulit sehat ranting Sengon dengan pelarut $\mathrm{n}$ heksana tidak terbentuk zona hambat. Diduga, hal ini dapat disebabkan oleh lapisan dinding Klebsiella pneumoniae dan Escherchia coli lebih tebal dibanding mikroorganisme uji yang lain. Selain itu, terdapat beberapa faktor yang dapat mempengaruhi hasil uji aktivitas antibakteri antara lain faktor teknis, faktor biologis dan faktor virologis. Faktor teknis diantaranya perbedaan waktu pra-difusi, ketebalan media agar, kerapatan inokulum, komposisi media agar, suhu inkubasi, waktu inkubasi, $\mathrm{pH}$, 
spesies bakteri dan potensi cakram antimikroba (Allo, 2016; Annissa, 2017).

Adapun perbedaan luas zona hambat yang terbentuk pada ekstrak kulit sehat ranting Sengon dengan pelarut metanol yang lebih kecil dibanding dengan pelarut etil asetat, diduga akibat penggunaan ekstrak yang berbeda. Pada ekstrak kulit sakit, senyawa metabolit sekunder yang dihasilkan lebih banyak dibandingkan pada ekstrak kulit sehat. Dugaan ini diperkuat oleh pernyataan Rumidatul (2018) yang menyatakan bahwa metabolit sekunder yang terserang oleh penyakit memiliki kadar yang lebih tinggi dibanding tanaman yang sehat. Sama halnya dengan kemampuan ekstrak kulit sehat dengan pelarut n-heksana terhadap Candida albicans, meskipun ekstrak kulit sehat ranting Sengon dengan pelarut metanol memiliki kandungan fenolik, flavonoid, saponin, dan tanin, senyawa tersebut tidak cukup adekuat untuk dapat menghambat pertumbuhan mikroorganisme uji dengan baik.

Kemampuan ekstrak kulit dan kayu ranting Sengon dalam menghambat pertumbuhan bakteri dan jamur dipengaruhi oleh senyawa metabolit sekunder yang terkandung dalam kulit dan kayu ranting sengon. Senyawa metabolit sekunder yang diduga terdapat di kulit sehat dan sakit serta kayu kayu sakit ranting Sengon antara lain steroid, terpenoid, fenolik, flavonoid, saponin dan tanin. Dugaan ini diperkuat dengan hasil penelitian uji fitokimia yang dilakukan oleh Fahrizal (2014) yang menyatakan bahwa kulit kayu sengon yang diekstrak dengan air mengandung senyawa flavonoid, saponin, tanin, steroid dan triterpenoid. Sejalan dengan Fahrizal, Rumidatul (2018) menyatakan bahwa pada kulit sakit ranting Sengon dengan pelarut $\mathrm{n}$-heksana, etil asetat dan metanol mengandung senyawa terpenoid, steroid, flavonoid dan fenolik. Pada ekstrak dengan metanol, ditemukan pula senyawa saponin dan tanin yang hanya dapat dihasilkan oleh pelarut polar. Dalam penelitiannya, Rumidatul (2018) juga menyatakan bahwa umumnya, produksi metabolit sekunder akan meningkat apabila tanaman terserang penyakit.

Mekanisme senyawa metabolit sekunder flavonoid dalam menghambat pertumbuhan bakteri yaitu membentuk ikatan dengan protein pada membran plasma yang dapat menyebabkan tegangan pada permukaan membran sel dan permeabilitas membran sel meningkat (Febrianasari, 2018). Mekanisme yang sama terjadi pada terpenoid, senyawa ini akan berikatan dengan protein, lipid dan karbohidrat yang terdapat pada membran sel, sehingga sel bakteri menjadi lisis (Maliana et al., 2013). Lain halnya dengan dua senyawa metabolit sebelumnya, senyawa steroid memiliki kemampuan berinteraksi dengan membran fosfolipid sel yang bersifat permeabel terhadap senyawa lipofilik. Interaksi ini akan menyebabkan integritas membran sel menjadi menurun dan morfologi membran sel menjadi rapuh dan mudah lisis (Rijayanti, 2014). Sedangkan mekanisme senyawa fenolik sebagai antibakteri yaitu dengan memutus ikatan silang peptidoglikan yang memudahkannya melewati dinding sel. Dalam dinding sel, senyawa ini akan merusak protein dan fosfolipid serta melarutkan komponen yang berikatan secara hidrofobik sehingga menyebabkan kebocoran nutrien sal dan meningkatkan permeabilitas membran sel (Lingga et al., 2015). Senyawa saponin dapat menyebabkan kebocoran protein dan enzim dari dalam sel bakteri dan dapat meningkatkan permeabilitas membran sel sehingga sel akan mengalami lisis. Senyawa tanin akan 
menyebabkan sel bakteri menjadi lisis dengan cara merusak dinding polipeptida dinding sel sehingga pembentukan dinding sel tidak sempurna yang menyebabkan kematian sel (Sapara et al., 2016).

Pada jamur, senyawa terpenoid dapat merusak organel-organel sel jamur serta dapat berperan sebagai pelarut yang mampu memasukkan senyawa metabolit sekunder lain ke dalam membran sel (Lestari, 2013). Sama seperti pada bakteri, senyawa flavonoid akan membentuk senyawa kompleks dengan protein terlarut yang menyebabkan gangguan permeabilitas membran sel jamur (Dewi et al., 2019). Berbeda dengan dua senyawa sebelumnya, senyawa steroid memiliki potensi antijamur dengan menghambat pembentukan ergosterol yang merupakan komponen polisakarida dinding sel dan mempunyai peran penting dalam pertunasan jamur (Kurniawan, 2015). Mekanisme senyawa fenol sebagai antijamur yaitu dengan mendenaturasi ikatan protein pada membran sel yang menyebabkan membran sel menjadi lisis pada kadar yang rendah dan koagulasi protein yang menyebabkan kematian sel pada kadar yang tinggi (Dewi et al., 2019)

\section{KESIMPULAN}

Ekstrak kulit dan kayu ranting sengon memiliki aktivitas antimikroba dan mampu menghambat pertumbuhan S. typhi, S. dysenteriae, C. albicans, $P$. mirabilis, $P$. aeruginosa dan $S$. aureus. Kayu sakit dengan pelarut etil asetat merupakan bagian paling efektif dalam menghambat pertumbuhan $S$. typhi dengan rerata zona hambat sebesar 5,5 $\mathrm{mm}$. Konsentrasi ekstrak kulit dan kayu ranting sengon yang efektif menghambat pertumbuhan bakteri dan jamur adalah konsentrasi $11 \mathrm{mg} / \mathrm{L}$. Adapun bakteri yang tidak dapat dihambat pertumbuhannya adalah Escherichia coli dan Klebsiella pneumonia.

\section{SARAN}

Berdasarkan hasil penelitian yang didapat, penulis ingin memberikan saran kepada peneliti selanjutnya untuk dilakukan pemurnian dan identifikasi terhadap senyawa yang terkandung dalam ekstrak kulit sehat dan sakit serta kayu sakit ranting sengon.

\section{UCAPAN TERIMAKASIH}

Terima kasih kepada Institut Kesehatan Rajawali yang telah membantu terlaksananya penelitian ini.

\section{DAFTAR PUSTAKA}

Allo MBR. 2016. Uji aktivitas antibakteri dari ekstrak air kulit buah pisang ambon lumut (Musa acuminata Colla) terhadap pertumbuhan Staphylococcus aureus.

https://repository.usd.ac.id/6854/2 /121434067_full.pdf (Diakses 07 Juni 2020)

Amalia A, Sari I, Nursanty R. 2017. Aktivitas Antibakteri Ekstrak Etil Asetat Daun Sembung (Blumea balsamifera (L.) DC.) Terhadap Pertumbuhan Bakteri Methicillin Resistant Staphylococcus aureus (MRSA). https://jurnal.arraniry.ac.id/index. php/PBiotik/article/download/216 $\underline{0 / 1611}$ (Diakses 7 September 2020)

Annissa. 2017. Uji aktivitas antibakteri senyawa difeniltimah(IV) di-3klorobenzoat dan trifeniltimah(IV)3-klorobenzoat terhadap bakteri gram negartif Pseudomonas auruginosa dan gram positif Bacillus sutilis http://digilib.unila.ac.id/27363/3/T 
ESIS\%20TANPA\%20BAB\%20P EMBAHASAN.pdf (Diakses 7 Juni 2020)

Benigna, M. 2015. Uji daya hambat ekstrak daun keji beling (Srobilanthes Crispa BI.) terhadap pertumbuhan bakteri Salmonella typhi secara in vitro. https://repository.usd.ac.id/981/2/ 111434032 full.pdf (Diakses 12 Oktober 2019).

Desrini S. Resistensi antibiotik, akankah dapat dikendalikan?. JKKI, 6(4):iiii.

Dewi S, Asseggar SNYRS, Natalia D, Mahyarudin. 2019. Efek ekstrak etanol daun kesum (Polygonum minus Huds.) sebagai antifungi terhadap Trychophyton rubrum. JKA, 8(2):198-203.

Dian E dan Djannatun T. Teknik firm agar untuk isolasi bakteri menjalar. http://academicjournal.yarsi.ac.id/ index.php/jurnal-fk-

yarsi/article/view/264 (Diakses 8 Agustus 2020)

Eleanore Y. 2013. Analisis fitokimia dan aktivitas antioksidan ekstrak daun sengon (Paraserianthes falcataria (L) Nielsen) menggunakan metode dpph.https://repository.ipb.ac.id/bi tstream/handle/123456789/65331/ G13yel.pdf?sequence $=1$ \&isAllow ed=y (Diakses 15 September 2019).

Elsas MD. 2014. Aktivitas antibakteri ekstrak daun sengon (Falcataria moluccana (L) Nielsen) terhadap bakteri Staphylococcus aureus dan Escherichia coli. https://id.123dok.com/document/4 yr7kd7q-aktivitas-antibakteriekstrak-daun-sengon-falcatariamoluccana-1-nielsen-terhadapbakteri-staphylococcus-aureusdan-escherichia-coli.html (Diakses 6 September 2019).

Eleanore Y. 2013. Analisis fitokimia dan aktivitas antioksidan ekstrak daun sengon (Paraserianthes falcataria (L) Nielsen) menggunakan metode dpph.https://repository.ipb.ac.id/bi tstream/handle/123456789/65331/ G13yel.pdf?sequence $=1 \&$ isAllow ed=y (Diakses 15 September 2019).

Fahrizal MD. Total fenolik dan flavonoid serta aktivitas antioksidan ekstrak kulit kayu sengon (Paraserianthes falcataria (L.)).https://repository.ipb.ac.id/bi tstream/handle/123456789/70448/ G14mdf.pdf?sequence $=1$ \&isAllo $\underline{\text { wed }=y}$ (Diakses 15 September 2019)

Fauziah P.N, Nurhajati J, Chrysanti. Pengaruh laju pertumbuhan dan waktu generasi terhadap penghambatan pertumbuhan koloni Klebsiella pneumoniae strain atcc 700603, ct1538, dan s941 oleh Lactobacillus bulgarius ks1 dalam soyghurt. http://stikesayani.ac.id/publikasi/e journal/filesx/2013/201304/20130 4-001.pdf (Diakses 6 Juni 2020)

Febrianasari F. 2018. Uji aktivitas antibakteri ekstrak daun kirinyu. https://repository.usd.ac.id/30997/ 2/141434020 full.pdf (Diakses 8 Juni 2020)

Hamdiyati Y. 2011. Pertumbuhan dan pengendalian mikroorganisme II. http://file.upi.edu/Direktori/FPMI PA/JUR. PEND.BIOLOGI/1966 11031991012-

YANTI_HAMDIYATI/Pertumbu han_pada_mikroorganisme_II.pdf (Diakses 8 Juni 2020).

Kayser FH, Bienz KA, Eckert J, Zinkernagel RM._2005. Medical microbiology. New York:Thieme.

Kurniawan D. 2015. Uji aktivitas antijamur ekstrak etanol daun kelor (Moringa oleifera Lamk.) terhadap Candida albicans secara 
in

vitro.

https://media.neliti.com/media/pu blications/193617-ID-ujiaktivitas-antijamur-ekstraketanol-d.pdf (Diakses 8 Juni 2020).

Lestari P.I. 2013. Aktivitas antifungi ekstrak daun teh terhadap pertumbuhan Aspergillus flavus. The Indonesian Journal of Infectious Disease. https://media.neliti.com/media/pu blications/261793-none469e41d4.pdf (Diakses 22 Agustus 2020)

Lingga AR, Pato U, Rossi E. Uji antibakteri ekstrak batang kecombrang (Nicolaia speciosa Horan) terhadap Staphylococcus aureus dan Escherichia coli. JOM Faperta, 3:1-15.

Maliana Y, Khotimah S, Diba F. Aktivitas antibakteri kulit Garcinia mangostana Linn. terhadap pertumbuhan Flavobacterium dan Enterobacter dari Coptotermes curvignathus Holmgren. Protobiont, 2:7-11.

Miradiana, Saidi N, Nursanty R. 2017. Potensi Ekstrak N-Heksana Daun Kapas (Gossypium hirsutum L.) Terhadap Bakteri Methicillin Resistant Staphylococcus aureus (MRSA). BioLeuser, 1(1):13-19.

Ngazizah FN, Ekowati N, Septiana AT. Potensi daun trembilungan (Begonia hirtella Link) sebagai antibakteri dan antifungi. Biosfera, 33:126-133.

Opa S.L., Bara R.A., Gerung G.S., Rompas R.M., Lintang R.A.J., Sumilat D.A. 2018. Uji Aktivitas Antibakteri Fraksi N-Heksana, Metanol dan Air dari Ascidian Lissoclinum sp. Jurnal Pesisir dan Laut Tropis, 1(1):69-80.

Pratiwi R.H. 2017. Mekanisme Pertahanan Bakteri Patogen Terhadap Antibiotik. Jurnal Pro-
Life, 4(3):418-429.

Rahayu S.A, Gumilar M.H. Uji cemaran air minum masyarakat sekitar margahayu raya bandung dengan identifikasi bakteri Escherichia coli. IJPST, 4:50-56.

Ristianti NP. 2015. Uji bioaktivitas Forbazol E terhadap hambatan pertumbuhan pada Staphylococcus aureus.

https://ejournal.undiksha.ac.id/ind ex.php/JST/article/view/4934

(Diakses 22 Agustus 2020)

Rosdiana NA. 2017. Bioaktivitas zat ekstraktif kulit dan mata kayu sengon (Paraserianthes falcataria L. Nielsen), mahoni (Swietenia mahagoni Jack), dan mangium (Acacia mangium Willd). https://repository.ipb.ac.id

(Diakses 25 Oktober 2019).

Rumidatul A. 2018. Potensi medik metabolit tanaman sengon (Falcataria moluccana) yang terserang penyakit karat tumor. http://www.sps.itb.ac.id/in/wpcontent/uploads/2018/04/abstrak alfi_rumidatul_2018.pdf (Diakses 6 Juni 2020)

Rumidatul A, Aryantha INP, Sulistyawati E. 2018. Potensi ekstrak ranting sengon (Falcataria moluccana Miq.) sebagai sumber atioksidan alami. http://digilib.uinsgd.ac.id/12784/1 /Full\%20Prosiding\%20Semabio\% 203\%202018\%20ok2.pdf

(Diakses 15 Desember 2019).

Ryan KJ, Ray CG. 2004. Sherris medical microbiology. $\quad 4^{\text {th }} \quad$ Ed. Arizona:McGrawHill.

Sahribulan. Rauf HD, Hasyim Z. Efek ekstrak kasar cacing tanah Pheretima sp. terhadap morfologi sel bakteri Salmonella typhi. Bionature, 19(2):152-162.

Sapara T.U., Waworuntu O., Juliatri. 2016. Efektivitas Antibakteri 
Ekstrak Daun Pacar Air (Impatiens balsamina L.) Terhadap Pertumbuhan Porphyromonas gingivalis. Pharmacon, 5(4):10-17. Tiolina ND. Pengujian aktivitas antibakteri ekstrak kulit rangon sengon (Paraserianthes falcataria) berumur 1-2 tahun dengan pelarut $\mathrm{n}$-heksan terhadap
Staphylococcus

aureus, Salmonella sp, dan Klebsiella sp. http://perpustakaan.stikesrajawali. ac.id/karyailmiah/js/zviewer/index .php?swf=5e1c1fe9abe4c664416c 1becfa10ff01c8931269.swf\&fid= 1027\&bid=766 (Diakses 12 


\section{Tabel 01}

Identifikasi Mikroba Uji

\begin{tabular}{|c|c|c|c|c|}
\hline No & Mikroba Uji & Morfologi Koloni & Morfologi Sel & $\begin{array}{c}\text { Hasil } \\
\text { Pewarnaan }\end{array}$ \\
\hline 1. & $\begin{array}{l}\text { Candida } \\
\text { albicans }\end{array}$ & $\begin{array}{c}\text { Koloni kecil, berbentuk } \\
\text { bulat dengan permukaan } \\
\text { mucoid, berwarna putih } \\
\text { dengan tepian halus dan } \\
\text { rata }\end{array}$ & $\begin{array}{l}\text { Berbentuk } \\
\text { blastoconodia, } \\
\text { berwarna ungu }\end{array}$ & $\begin{array}{l}\text { Gram } \\
\text { positif }\end{array}$ \\
\hline 2. & $\begin{array}{c}\text { Salmonella } \\
\text { typhi }\end{array}$ & $\begin{array}{l}\text { Koloni sedang, berbentuk } \\
\text { bulat, elevasi cembung } \\
\text { dengan permukaan halus, } \\
\text { berwarna } \\
\text { putih/translucen }\end{array}$ & $\begin{array}{l}\text { Berbentuk basil } \\
\text { tunggal, berwarna } \\
\text { merah }\end{array}$ & $\begin{array}{l}\text { Gram } \\
\text { negatif }\end{array}$ \\
\hline 3. & $\begin{array}{c}\text { Klebsiella } \\
\text { pneumoniae }\end{array}$ & $\begin{array}{l}\text { Koloni sedang, berbentuk } \\
\text { bulat beraturan, elevasi } \\
\text { cembung dengan } \\
\text { permukaan mucoid, } \\
\text { berwarna putih } \\
\text { susu/buram }\end{array}$ & $\begin{array}{l}\text { Berbentuk basil } \\
\text { pendek } \\
\text { berpasangan, } \\
\text { berwarna merah }\end{array}$ & $\begin{array}{l}\text { Gram } \\
\text { negatif }\end{array}$ \\
\hline 4. & $\begin{array}{c}\text { Shigella } \\
\text { dysenteriae }\end{array}$ & $\begin{array}{l}\text { Koloni kecil, berbentuk } \\
\text { bulat beraturan, elevasi } \\
\text { cembung dengan } \\
\text { permukaan halus, } \\
\text { berwarna putih } \\
\text { bening/translucent }\end{array}$ & $\begin{array}{l}\text { Berbentuk basil } \\
\text { pendek tunggal, } \\
\text { berwarna merah }\end{array}$ & $\begin{array}{l}\text { Gram } \\
\text { negatif }\end{array}$ \\
\hline 5. & $\begin{array}{l}\text { Escherchia } \\
\text { coli }\end{array}$ & $\begin{array}{l}\text { Koloni kecil, berbentuk } \\
\text { bulat beraturan, elevasi } \\
\text { cembung dengan } \\
\text { permukaan halus, } \\
\text { berwarna putih } \\
\text { susu/buram. }\end{array}$ & $\begin{array}{l}\text { Berbentuk basil } \\
\text { pendek tunggal, } \\
\text { berwarna merah }\end{array}$ & $\begin{array}{l}\text { Gram } \\
\text { negatif }\end{array}$ \\
\hline 6. & $\begin{array}{l}\text { Proteus } \\
\text { mirabilis }\end{array}$ & $\begin{array}{l}\text { Koloni sedang, berbentuk } \\
\text { bulat, cembung, tepian } \\
\text { tidak rata, menjalar. }\end{array}$ & $\begin{array}{l}\text { Berbentuk basil } \\
\text { pendek, } \\
\text { berkelompok, dan } \\
\text { berwarna merah }\end{array}$ & $\begin{array}{l}\text { Gram } \\
\text { negatif }\end{array}$ \\
\hline 7. & $\begin{array}{c}\text { Pseudomonas } \\
\text { aeruginosa }\end{array}$ & $\begin{array}{c}\text { Koloni kecil, berbentuk } \\
\text { bulat, konsistensi kasar, } \\
\text { tepian tidak rata, } \\
\text { menjalar. }\end{array}$ & $\begin{array}{l}\text { Berbentuk basil, } \\
\text { rantai pendek, dan } \\
\text { berwarna merah }\end{array}$ & $\begin{array}{c}\text { Gram } \\
\text { negatif }\end{array}$ \\
\hline 8. & $\begin{array}{c}\text { Staphylococcus } \\
\text { aureus }\end{array}$ & $\begin{array}{l}\text { Koloni kecil, berbentuk } \\
\text { bulat, konsistensi halus, } \\
\text { tepian rata, tidak } \\
\text { menjalar. }\end{array}$ & $\begin{array}{l}\text { Berbentuk kokus, } \\
\text { bergerombol } \\
\text { (seperti buah } \\
\text { anggur), dan } \\
\text { berwarna ungu }\end{array}$ & $\begin{array}{l}\text { Gram } \\
\text { positif }\end{array}$ \\
\hline
\end{tabular}


Tabel 02

Kurva Tumbuh Bakteri

\begin{tabular}{|c|c|c|c|c|c|c|}
\hline \multirow[t]{2}{*}{ No } & \multirow[t]{2}{*}{ Jenis Bakteri } & \multicolumn{4}{|c|}{ Fase (jam ke-) } & \multirow{2}{*}{$\begin{array}{c}\text { Waktu } \\
\text { Optimum } \\
\text { (jam ke-) }\end{array}$} \\
\hline & & Lag & $\log$ & Stasioner & Kematian & \\
\hline 1. & Candida albicans & $0-6$ & $12-54$ & $60-84$ & $90-120$ & 30 \\
\hline 2. & Salmonella typhi & $0-3$ & $6-24$ & $27-36$ & 39 & 18 \\
\hline 3. & Klebsiella pneumoniae & $0-3$ & $6-27$ & $30-39$ & $42-48$ & 18 \\
\hline 4. & Shigella dysenteriae & $0-3$ & $6-24$ & $27-36$ & 39 & 15 \\
\hline 5. & Escherchia coli & $0-3$ & $6-24$ & $27-39$ & $42-48$ & 15 \\
\hline 6. & Proteus mirabilis & $0-12$ & $15-24$ & $27-39$ & 42 & 21 \\
\hline 7. & Pseudomonas aeruginosa & $0-3$ & $6-24$ & $27-33$ & 36 & 12 \\
\hline 8. & Staphylococcus aureus & 0 & $3-21$ & $24-36$ & 39 & 6 \\
\hline
\end{tabular}

Tabel 03

Hasil Pengukuran Rerata Diameter Zona Hambat Ekstrak Kulit Sehat dan Sakit serta Kayu Sakit Ranting Sengon dengan Pelarut n-Heksana, Etil Asetat dan

Metanol terhadap Mikroorganisme Uji

\begin{tabular}{|c|c|c|c|c|c|c|c|c|}
\hline \multirow[b]{2}{*}{ No. } & \multirow[b]{2}{*}{ Mikroba Uji } & \multirow{2}{*}{$\begin{array}{c}\text { Kontrol } \\
- \\
(\mathbf{m m})\end{array}$} & \multirow{2}{*}{$\begin{array}{c}\text { Kontrol } \\
+ \\
(\mathrm{mm})\end{array}$} & \multicolumn{5}{|c|}{ Zona Hambat pada Konsentrasi (mm) } \\
\hline & & & & $\begin{array}{c}11 \\
\mathrm{mg} / \mathrm{dl}\end{array}$ & $\begin{array}{c}10,5 \\
\mathrm{mg} / \mathrm{dl}\end{array}$ & $\begin{array}{c}10 \\
\mathrm{mg} / \mathrm{dl}\end{array}$ & $\begin{array}{c}9,5 \\
\mathrm{mg} / \mathrm{dl}\end{array}$ & $\begin{array}{c}9 \\
\mathrm{mg} / \mathrm{dl}\end{array}$ \\
\hline 1 & Escherichia coli ${ }^{l}$ & 0 & 10,3 & 0 & 0 & 0 & 0 & 0 \\
\hline 2 & $\begin{array}{c}\text { Klebsiella } \\
\text { pneumoniae }\end{array}$ & 0 & 13.3 & 0 & 0 & 0 & 0 & 0 \\
\hline 3 & Shigella dysenteriae ${ }^{1}$ & 0 & 16 & 7.3 & 6 & 4.4 & 1.8 & 0 \\
\hline 4 & Candida albicans ${ }^{l}$ & 0 & 15 & 6.9 & 5.5 & 4.4 & 3.6 & 3 \\
\hline 5 & Salmonella typhi ${ }^{1}$ & 0 & 12 & 2.9 & 2.5 & 2.3 & 2 & 0 \\
\hline 6 & Salmonella typhi ${ }^{2}$ & 0 & 12 & 4.7 & 2.9 & 2.5 & 2.4 & 2.4 \\
\hline 7 & Salmonella typhi ${ }^{3}$ & 0 & 12 & 9.1 & 5.6 & 4.9 & 4.2 & 3.7 \\
\hline 8 & Proteus mirabilis ${ }^{4}$ & 0 & 17 & 4.7 & 3.3 & 2 & 1.3 & 1.3 \\
\hline 9 & $\begin{array}{l}\text { Pseudomonas } \\
\text { aeruginosa }^{4}\end{array}$ & 0 & 5 & 4.3 & 4.3 & 3.3 & 3.3 & 0 \\
\hline
\end{tabular}




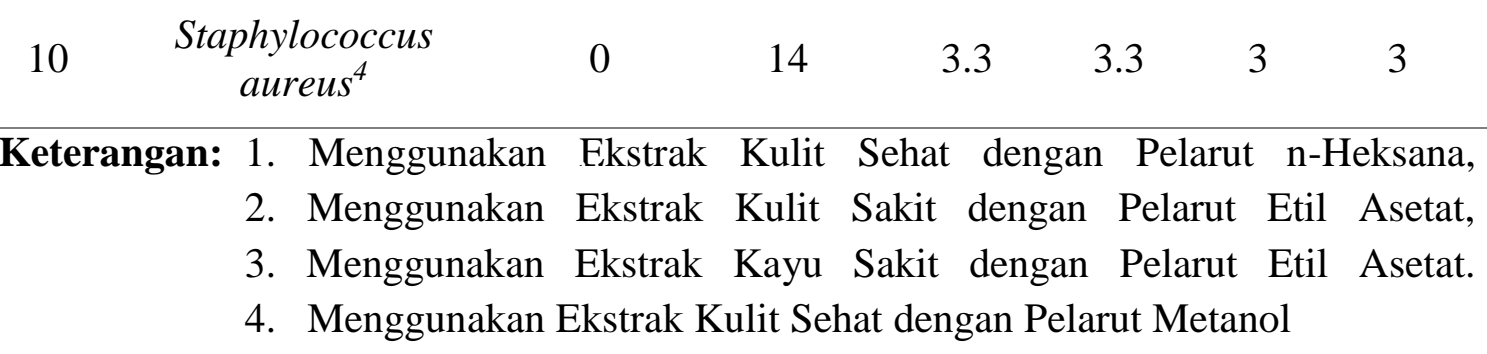

